\title{
A COUNTERFEIT ABBASID DINAR FROM THE ERA OF CALIPH HARUN AL- RASHID MINTED IN EGYPT IN 176 A.H. / 792 A.D. IN THE NAME OF MUSA IBN ISA
}

\author{
Zarazir, M.
}

Islamic Archaeology dept., Faculty of Archaeology, Sohag Univ., Sohag, Egypt E-mail address: mahmoud.zarazir@arch.sohag.edu.eg

\begin{tabular}{|c|c|}
\hline Article info. & EJARS - Vol. 10 (2) - Dec. 2020: 189-196 \\
\hline Article history: & Abstract: \\
\hline $2-2020$ & Counterfeiting of coins is an economic problem to states. It took \\
\hline $3-11-2020$ & many forms but was not limited to the eras of weakness and the \\
\hline $.21608 /$ ejars.2020.134222 & $\begin{array}{l}\text { collapse of the economy. Rather, it sometimes took place in some } \\
\text { eras of strength. The counterfeit dinar under study is a piece of }\end{array}$ \\
\hline $\begin{array}{l}\text { Keywords: } \\
\text { Counterfeiting }\end{array}$ & $\begin{array}{l}\text { evidence. It was counterfeited in one of the greatest periods of } \\
\text { the First Abbasid Period at the time of Caliph Harun al-Rashid } \\
\text { (170-193 A.H./786-809A.D.) in the name of prince Musa ibn Isa of }\end{array}$ \\
\hline Dinar & the Abbasid Dynasty who was a ruler of Egypt for the second \\
\hline Musa ibn Isa & time. It was minted using a mold dedicated to counterfeit dinars \\
\hline Coating & that might be used for an entire set of dinars. The Graeco-Roman \\
\hline Gilding & 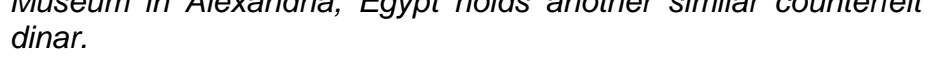 \\
\hline
\end{tabular}

\section{Introduction}

The present study investigates a counterfeit dinar minted in Egypt in (176 A.H.) in the name of the ruler of Egypt prince Musa ibn Isa at the time. The dinar is kept at the American Numismatic Society ${ }^{(a)}$. It is compared to another dinar kept at the GraecoRoman Museum in Alexandria, Egypt [1]. The study begins by addressing the counterfeiting of coins in terms of concept, method, and style. Counterfeiting (of coins) is one of the issues that spread over time. It was mostly motivated by the political, economic, and social unrest in the country. Such circumstances were exploited to gain money, especially at times of weakness and degradation. However, counterfeiting sometimes took place at times of strength, such as the era under investigation, which may raise questions. In this era, the main coin, i.e. dinar was counterfeited in Egypt that had one of the most important mints across the Abbasid Era. The name of the ruler of Egypt prince Musa ibn Isa; a cousin of Caliph Harun Al-Rashid was inscribed.

\subsection{Counterfeiting}

In Arabic, Zaif (forgery/counterfeiting) is taken from a description of the dirham. For example, dirhams were counterfeited means that they became unacceptable for counterfeiting. Ibn Saidah reported that the dirham was counterfeited. The singular is zaief (pl. zoyyf, zyyaf, or zyuf) to mean counterfeited [2]. Muslims called counterfeit coins "zaif", "zaief", and "mozaief" to indicate coins of low-quality [3]. Counterfeit coins are not acceptable in transactions. Coins are counterfeited when the amount of cheap metals increases. They were accepted in commercial transactions only because the government did not accept these coins in its transactions or tax collection. In addition, the government punished the holders of such coins [3]. Counterfeiting 
was not limited to one method. Rather, it took many forms based on the metal used, i.e. (gold) for dinars, (silver) for dirhams, or (cooper) for fulus. Thus, various terms indicated this illegal action, such as:

*) Niello (Takfet) means inserting a desk of copper between two layers of silver. Then, coins are minted, texts are inscribed, and cooper disappears. Some dinars were counterfeited by kohl and known as mokahal dinars. In this case, the sides, margins/ rims, and reverse of the dinar are engraved. Then, the holes are filled with kohl. This form is often fixed by the origins and among letters [3].

*) Gloss (Camouflage): Glossing something means painting it with gold or silver or using low-quality materials, including copper or iron. It means minting a dinar and painting it with gold or minting copper dirhams and covering them with silver externally to be seen as silver. After a short period, the glossed copper appears [3].

\subsection{Emir of Egypt Musa ibn Isa}

Musa ibn Isa ibn Musa ibn Muhammad ibn Aly ibn Abdullah ibn Al-abbas [4-6] ibn Abdelmotaleb ibn Hashim was appointed emir (ruler) of Egypt three times by Caliph Harun al-Rashid. His place of residence was Al-Askar [7]. He came to the throne for the first time for a year and five and a half months from Rabi' al-awwal 171 A.H. to Ramadan 172 A.H. and he was in charge of Salah (prayer) only [4,5]. In the second term, he ruled from Safar 175 A.H. [4,5] to the removal from the throne in Safar 176 A.H. [5]. Historians argue that he was removed from the throne because he tried to rebel against Caliph al-Rashid and set Egypt independent from subordination to the Abbasid era [6,8-12]. His term took a year. He was in charge of prayer and Kharaj (Tax on agrarian land owned by non-Muslims) [4,5], indicating the increase of his powers ${ }^{(b)}$ [13]. The third term was from Ramadan 179 to Jumada al-
Akhirah 180 A.H. He was in charge of prayer [4].

\section{Case Studies}

On the counterfeit dinar under study, fig. (1-a \& b), the recognized texts of Abbasid dinars of the time were inscribed. In the center of the obverse, a form of the Islamic Testimony of Faith (Shahāda Tawheed) (La ilaha illa/ llahu wahdahu/ la sharika lahu) was inscribed in three lines. A Qur'anic citation (Muhammad Rasul Allah Arsalahu Bil Huda Wa Din Al Hakk Lyuzhirahu 'Ala Al-Din Kulahu) was on the margin. The center of the reverse contained the Muhammad Mission in three lines followed by Musa on the fourth (Muhammad/ Rasul/ Allah/ Musa). In the margin, (Besm Alelh Durb Hadha Aledyenr Sanat Set Wesb'eyen Wema'eh) was inscribed. This dinar is one of the unique counterfeit dinars discovered in the First Abbasid era at the time of Caliph Harun alRashid. It is presented on the website of the American Numismatic Society, fig. (1a). Although its data are recorded well, some data require revision and examination. 1) It was reported that the metal used for manufacturing is gold (Material: Gold), which is incorrect because the dinar is made of silver that is manifested clearly in the shape and color of the piece. A comparison with the counterfeit dinar made of silver and kept at the Graeco-Roman Museum in Alexandria, Egypt shows the same. Because their data match, the metal is the same. 2) The notes' section of the website illustrates that the dinar is counterfeit in a contemporary or modern era (Note: counterfeit contemporary or modern). No decisive decision was taken concerning the period of counterfeiting. Was it counterfeited in the Abbasid era? Has it been counterfeited recently to be sold on international auctions as a rare piece? By studying and examining this piece and reviewing the historical events of the year of minting, 
the study concludes that counterfeiting was carried out in the inscribed year on the piece, i.e. the reign of Caliph Harun al-Rashid. This finding is demonstrated by the similarity between the examined dinar and the one kept at the GraecoRoman Museum in Alexandria, Egypt. This collection has been kept for a long time in the Museum. Its data were not revealed but after the study of Atef Mansur (2007) [1]. Accordingly, it could be concluded that both counterfeit dinars represent a complete set minted at the time for circulation. Comparing the investigated counterfeit dinar and the dinar kept at the Graeco-Roman Museum in Alexandria, Egypt to a real dinar minted in (175 A.H. / 791 A.D. $)^{\text {(c) }}$, fig. (2-a) on which the name of Prince Musa ibn Isa and the same writings were inscribed but with a different date shows that: 1) The counterfeit dinar was minted using a mold dedicated to counterfeit dinars. It was not minted by mistake using the mold of minting dirhams and fulus. That is, counterfeiting is intentional. Moreover, several pieces were minted at the time, as shown by the dinar kept at the Graeco-Roman Museum in Alexandria. 2) The mold used for minting the counterfeit dinar under study differs from the official mold of minting used for the dinar of 175 A.H. and other dinars around the time. This finding is manifested in the general shape of both dinars and other dinars minted before and after 176 A.H. that was reviewed. 3) The distribution of the words in the centers of the obverse and the reverse differs in terms of the beginning of statements and the position of words to demonstrate the mismatch of the mint molds used for the two dinars. This finding supports the argument that the counterfeit dinar was minted outside the official mint. 4) The style of implementing writings differs completely. The counterfeit dinar lacks accuracy in implementing its letters, whereas the original dinar minted in 175 A.H. / 791 A.D. has the features of Abbasid dinars minted before or later in the official Mint, fig. (2-b). 5) The inscription of letters in the investigated counterfeit dinar is inaccurate. Most of them end with dots, which are hollow in some positions. Additionally, (mīm ค, wāw و, hầi ه, and ḍād ض) letters are more hollow. Such cavities might be made to collect the largest amount of the gilded material to fix gilding and not to discover counterfeiting easily, fig. (2-b). Accordingly, the coin under study is an Abbasid dinar minted in the Abbasid State for circulation. In other words, counterfeiting is old, not modern. Gloss was the method. The dinar was made of silver and painted with gold, as shown from the remains of the golden color in some positions, fig. (2-c).

\begin{tabular}{|c|c|c|}
\hline & Obverse & Reverse \\
\hline \multirow{8}{*}{ 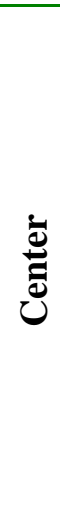 } & La ilaha illa (لا اله الا & Muhammad (مح) \\
\hline & llahu wahdahu ( الله وحده ) & Rasul (رسول) \\
\hline & Fig. (1): Extracting the writings of a & Allah (الله) \\
\hline & counterfeit dinar minted in Egypt in & Musa (موسى) \\
\hline & 176A.H. (by the researcher)la sharika & (Muhammad is the messenger of Allah Musa) \\
\hline & lahu (لا شريك له) & \\
\hline & (There is no god but Allah, the One, & \\
\hline & having no partner with Him.) & \\
\hline
\end{tabular}




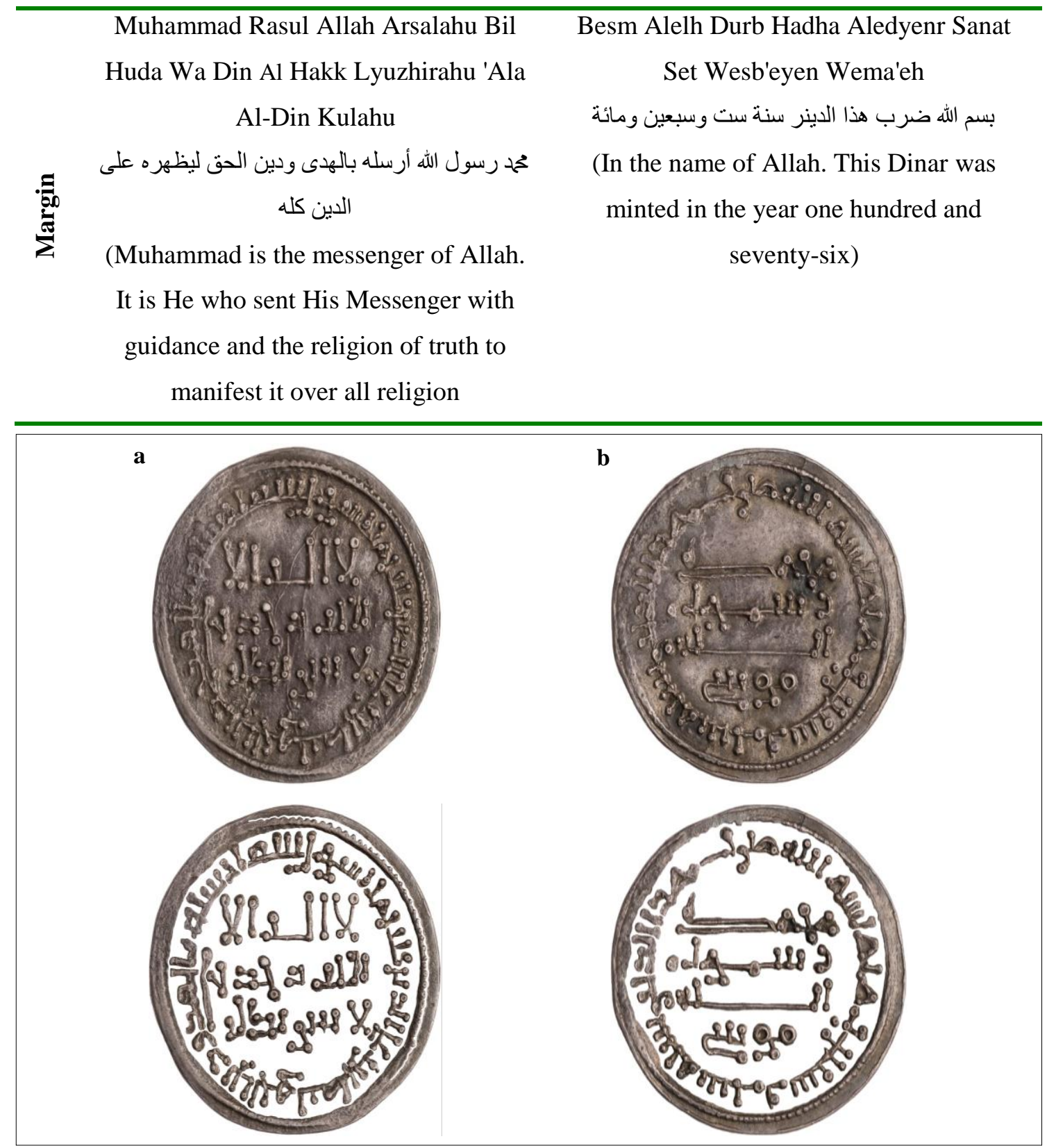

Figure (1) Shows a. a counterfeit dinar minted in Egypt in 176A.H. with the name of Musa Axis: 5, Weight: 2.299, Diameter: 21; American Numismatic Society, no. 1951.147.4, ‥ extracting the writings of a counterfeit dinar minted in Egypt in 176A.H.

\begin{tabular}{lcc}
\hline & Obverse & Reverse \\
\hline \multirow{4}{*}{ Center } & La ilaha illa & Muhammad \\
& llahu wahdahu & Rasul \\
& la sharika lahu & Allah \\
& & Musa \\
Margin & Muhammad Rasul Allah Arsalahu Bil & Besm Alelh Durb Hadha Aledyenr Sanat \\
& Al-Din Kulahu & Khams Wesb'eyen Wema'eh \\
\hline
\end{tabular}



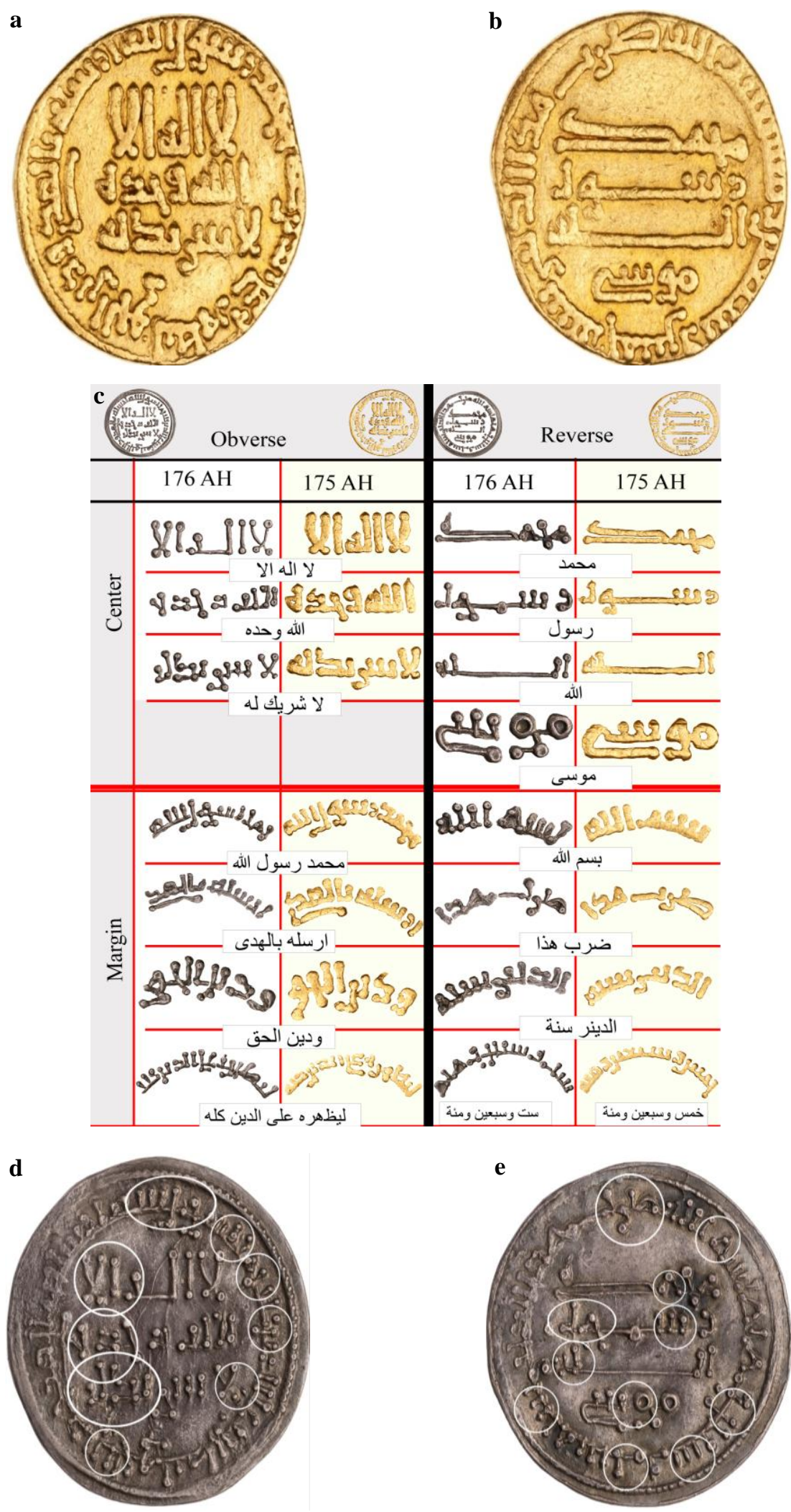

Figure (2) Shows $\underline{\mathbf{a}} . \& \underline{\mathbf{b}}$. a dinar minted in Egypt in 175 A.H. with the name of Musa Axis: 0, Weight..., Diameter: ...; American Numismatic Society, no. 1971.49.187, c. comparison between the investigated counterfeit dinar 176 A.H., to a real dinar, $\underline{\mathbf{d}}$. \& $\underline{\mathbf{e}}$. golden color in some position of a counterfeit dinar minted in Egypt in 176 A.H; Axis: 5, Weight: 2.299, Diameter: 21, (American Numismatic Society, no. 1951.147.4) 


\subsection{Weight}

After wearing off the golden paint according to the published data, the dinar weights (2.299 grams), which is largely natural and indicates that the dinar is close to the legal weight of (4.25 grams) when the gilding material existed. In other words, counterfeiters were keen on having such counterfeit dinars in an adequate weight close to the common legal one in the official mint in Egypt at the time. Taking this step, the counterfeiters aimed to increase the opportunity of accepting the dinars in circulation and to prevent doubts. To stress this issue, the weights of dinar models minted in the reign of Caliph Harun al-Rashid in the official mint of Egypt around 176 A.H. were compared, tab. (1). Taking into account the present weights of dinars and the small difference from the legal weight $(4.25 \mathrm{gm})$ that might be lost because of different factors, it could be stressed that the official mint of Egypt adhered to the legal weight. This aspect can be one of the most important causes that motivated counterfeiters mint this counterfeit dinar in Egypt.

Table (1) Weights of some dinars minted in Egypt in the given years

\begin{tabular}{cccccc}
\hline $\begin{array}{c}\text { Year of } \\
\text { Mint }\end{array}$ & 174 A.H. & 175 A.H. & 176 A.H. & 177 A.H. & 178 A.H. \\
\hline Weight & $4.22 \mathrm{gm}^{(\mathrm{d})}$ & $\begin{array}{r}4.20 \mathrm{gm}^{(\mathrm{e})} \\
4.23 \mathrm{gm}^{(\mathrm{f})}\end{array}$ & $4.24 \mathrm{gm}^{(\mathrm{g})}$ & $4.16 \mathrm{gm}^{(\mathrm{i})}$ & $4.23 \mathrm{gm}^{(\mathrm{i})}$ \\
\hline
\end{tabular}

\subsection{Mint}

The counterfeiters of the dinars understudy chose the official mint of Egypt because it was one of the most important mints in the Abbasid Era, especially in the First Abbasid Era because of its considerable status. Its coins were widely accepted in the exchange markets because of its high weight. Moreover, Egypt had considerable status in the Abbasid State, especially with its diverse resources and the passage of several international trades. The official mint (Egypt) was not inscribed explicitly on both counterfeit dinars following the roles of the official Mints. This was the case of dinars since the Arabization of coins in the reign of Caliph Abd al-Malik ibn Marwan to Caliph Al-Ma'mun. In short, counterfeiters minted it to suit the historical period of circulation as a forged model of the official dinar. This finding is evidence that the dinar was counterfeited in the reign of Caliph Harun al-Rashid in the First Abbasid Era.

\subsection{Musa}

The name (Musa) was inscribed on these counterfeit dinars in the same position where the name of the ruler of Egypt is inserted. He enjoyed a good reputation among the Egyptians because of his great works [4$6,14]$. This aspect was one of the most significant causes of inscribing his name on the collection. Furthermore, the events of 176 A.H. / 792 A.D. had a great relationship with selecting this ruler only. The study argues that this dinar was minted in 176 A.H. / 792 A.D. because 1) The political events, including the removal of prince Musa ibn Isa in the early 176 A.H. / 792 A.D. when he was about to rebel against Caliph Harun al-Rashid who removed him from office as reported by historians. The counterfeiters exploited these events with their rumors, violations, and lack of market control to circulate them without being noticed. 2) Minting this counterfeit dinar might be issued by prince Musa ibn Isa himself in the official mint, especially after controversy with Caliph Harun al-Rashid. No model dinar minted in Egypt in 176 A.H. / 792 A.D. in the name of prince Musa ibn Isa has been discovered yet but the counterfeit dinars were reported in the present study.

\section{Results}

The study concluded that the counterfeit dinars under study are the first discovered ones dating back to the first Abbasid era at the time of Caliph Harun al-Rashid. They indicate that a large collection was minted in this year with the same inscription. They are the only models minted in 176 A.H. in the name of Musa ibn Isa. The dinar of the American Numismatic Society was counterfeited in the method 
of gloss. It was minted in silver and painted in gold. It was minted using a special mold for counterfeit dinars outside the official mint. Colorful remains of gold used in the paint are in some parts of the dinar. Furthermore, the method of the inscriptions suggests that they were made to fix gold on the dinar.

\section{Discussion}

The study addressed an important economic issue facing ever, i.e. counterfeiting of coins. It examined a counterfeit dinar and compared it to another dinar kept at the Graeco-Roman Museum in Alexandria, Egypt. The data published by the American Numismatic Society on the counterfeit dinar were discussed. The present study demonstrated that this dinar was counterfeited in the Abbasid era, refuting the hypothesis of the American Numismatic Society that the dinar was counterfeited in the modern age. Furthermore, the study discussed inscribing the name of the ruler of Egypt, Musa ibn Isa only because of his good reputation among the Egyptians and his political controversy with Caliph Harun al-Rashid who removed him from office in the early 176 A.H. The study argued that these issues were exploited by the counterfeiters to mint this collection of dinars. Musa ibn Isa might be the one who ordered minting this counterfeit dinar in the era of al-Rashid. The study also discussed the weight of the examined counterfeit dinar, its relationship to the official weights of dinars made by the official mint of Egypt at the time, and its relationship to selecting Egypt to mint these counterfeit dinars. It compared the inscriptions of this dinar to those of official dinars minted in 175 A.H. in the name of Musa ibn Isa. This finding was demonstrated by the clear differences between the two pieces in terms of the mold, the style and form of writing, and the remains of the golden paint.

\section{Conclusion}

The examined coin is a counterfeit glossed dinar minted in the Abbasid era. It is a complete collection minted for circulation from which the examined dinar and a similar one at the Graeco-Roman Museum in Alexandria, Egypt were discovered. Texts similar to those of the original dinars were inscribed. Additionally, the name of the ruler of Egypt Musa ibn Isa was inscribed, and its weight was approximate to those of the official mint in Egypt at the time to facilitate circulation without arousing suspicion.

\section{Endnotes}

(a)American Numismatic Society, no. 1951. 147.4

(b) Al-Mawardi reported the details of coming to throne (as a ruler of a state) reporting, "If the Caliph appoints an emir over a province or a town, his emirate may be one of two kinds, either general or particular. As for the general form, it is of two kinds: either that freely contracted by the Caliph with the person chosen specifically for the task, or that contracted at times of conquest in compelling circumstances. As for the emirate which has been specifically and freely assigned, it comprises a clearly defined task and a clearly determined jurisdiction: The Caliph delegates the emirate of a country or province to the person appointed for this task and accords the right of governance over all its people together with jurisdiction over the customary acts of his office: He thus assumes a general responsibility for a particular territory and for specific and clearly defined tasks, and his corresponding jurisdiction covers seven matters, etc. Special emirate refers to that in which the emir is restricted to the organization of the army, establishment of public order, defense of the territory and protection of what is inviolable; it is not, however, up to him to undertake responsibility for the judiciary and the rulings of jurisprudence, or for the kharaj and sadakat.

(c) American Numismatic Society, no. 1971. 49.187.

(d)Baldwin's Auctions Ltd, Islamic Coin Auction 24, 09.05.2013, lot. 4234.

(e)Stephen Album Rare Coins, Auction 37, 11 June 2020, Lot. 275. 
(f) Baldwin's Auctions Ltd, Islamic Coin Auction 24, 09.05.2013, lot. 4226.

(g) Baldwin's Auctions Ltd, Islamic Coin Auction 24, 09.05.2013, lot. 4227.

(h) Baldwin's of St. James's, Auction 37, 25.09.2019, Lot. 196.

(i) Baldwin's Auctions Ltd, Islamic Coin Auction 24, 09.05.2013, lot. 4228.

\section{References}

[1]Ramadan, A. (2007). Alnuqd alislamia almahfouza fi-lmathaf alyunany arrumany bil-iskanndradia (Islamic coins kept at the Graeco-Roman Museum in Alexandria). SCA, Egypt.

[2]Ibn Manzur, M. (1984). Lisan alarab (Tongue of arabs), Part IX, Dar Almaaref, Cairo.

[3]Zahrani, D. (1993). Zaif alnuqud alislamia (Counterfeiting of islamic coins), $1^{\text {st }}$ ed., Makkah Al-Mukarramah, KSA.

[4]Alkandy, A. (1908). Kitab alwala wa kitab alquda (The book of rulers and the book of judges), Jesuit Fathers Press, Beirut.

[5]Al-Maqrizi, A. (1998). Alkhotat alMaqriziah: Almawaez wa-litibar bi-dhkr alkhotat wal-athar (Maqrizi plans: Lessons and consideration by reporting plans and monuments), Part I, Madbouly Bookshop, Cairo.

[6]Ibn Taghribirdi, A. (1992). Al-nujūm al-zāhirah fì mulūk Miṣr wa-al-Qāhirah
(Chronicle of the Kings of Egypt and Cairo), Part II, $1^{\text {st }}$ ed., Dar Alkotob Alilmia, Beirut

[7]Kashif, S. (1994). Mṣr fĭ f̆gr Al-islām mn al-fth Al-'rbì ili qīàm al-dūl̈̈ Alțülünït (Egypt in the down of Islam from Arab conquest to the Tulunid dynasty), General Egyptian Book Organization, Egypt.

[8]Al-Tabari, M. (1962). Tarikh al-rusul wa al-muluk (History of the prophets and kings), Part VIII, $2^{\text {nd }}$ (ed.) Dar Almaaref, Egypt.

[9] Ibn al-Jawzi, A. (1992). Al-mntżm fi tārīh al-mlūk wāl amm (Handbook of the history of kings and nations), Part IX, Dar Alkotob Alilmia, Beirut.

[10]Ibn al-Athir, A. (1987). Al-Kāmil fì altārīkh (The complete history), Part V, Dar Alkotob Alilmia, Beirut.

[11]Sibt ibn al-Jawzi, Y. (2012). Mir'at al-zamān fi tawarīkh al-'nyān (Mirror of time in histories of the notables), $1^{\text {st }}$ ed., Dar Arresala Alalamya, Syria.

[12]Ibn Kathir, A. (1998). Al-bidāya wan-nihaya (The beginning and the end), Part XIII, $1^{\text {st }}$ ed., Dar Hajar, Egypt.

[13]Al-Mawardi, A. (2006). Al-ahkam alsultania (The ordinances of government), Dar Alhadith, Cairo.

[14]Ibn Zulaq, A. (1999). Feda'el Mesr wakhebarha wekhewasha (Virtues, news, and characteristics of Egypt), General Egyptian Book Authority, Egypt. 